\title{
Biografická glosa: Šedesátiny Františka Znebejánka
}

V květnu 2011 oslavil významné životní jubileum PhDr. František Znebejánek, Ph.D., odborný asistent na Katedře sociologie a andragogiky Filozofické fakulty Univerzity Palackého v Olomouci. V neposlední řadě tak ovšem jubiluje také významný člen redakční rady časopisu Historická sociologie.

František Znebejánek vystudoval v roce 1974 na Filozofické fakultě v Olomouci obor pedagogika dospělých se zaměřením na sociologii práce a průmyslového podniku. V roce 1995 získal doktorát ze sociologie, jeho disertační práce vyšla v roce 1997 pod názvem Sociální hnutí: teorie, perspektivy v nakladatelství SLON. Dále je jubilant autorem dvou učebnic a mnoha článků týkajících se především sociologické teorie.

Po celý svůj profesní život je kolega Znebejánek zaměřen na sociologii. Pracoval jako sociolog v sociologicko-psychologickém středisku generálního ředitelství Ostravskokarvinských dolů a poté až do roku 1990 jako výzkumný pracovník ve Výzkumném ústavu paliv a energetiky v Ostravě. Od roku 1990 pracuje jako vysokoškolský učitel na Filozofické fakultě Univerzity Palackého a v roce 1992 byl rovněž členem Komise pro vzdělávání dospělých a sociální změnu Rady Evropy. Mnoho let byl aktivní jako akademický koordinátor Českého programu pro Associated Colleges of the Midwest, U.S.A., několikrát pobýval na zahraničních studijních pobytech (University of East Anglia, U.K., University of Chicago, U.S.A.). V letech 2002-2005 byl členem redakční rady Sociologického časopisu a v následujícím období 2000-2005 členem Komise pro sociologii v Grantové agentuře České republiky.

František Znebejánek vždy byl a zůstává sociologem, který netouží po slávě ani bohatství a raději si celý život klade náročné otázky, na něž usilovně hledá odpovědi. Jeho hlavním profesním zájmem je sociologická teorie, přičemž svůj zájem o ni spojuje se studiem historických událostí, především v období vývoje modernity. Je otevřený všem sociologickým perspektivám a paradigmatům, přesto je možné říci, že jeho hlavní orientaci představuje pragmatismus. Inspiruje ho filosofie Williama Jamese a Richarda Rortyho, ovlivněn byl také Georgem Simmelem a symbolickým interakcionismem. V centru jeho aktuálního vědeckého zájmu stojí analýza možností proměn sociálního jednání z konfliktního do kooperativního a z kooperativního do konfliktního. Velkou pozornost přitom věnuje také problematice metodologií společenských věd.

František Znebejánek je člověkem, který přirozeně inspiruje všechny, kdo se s ním při nejrůznějších příležitostech setkávají. Snaží se organizovat sociologické a mezioborové neformální diskusní kroužky, v rámci nichž zůstává vždy přátelský a pracovitý. Do dalších let mu přejeme spoustu zajímavých otázek a mnoho sil na jejich řešení, samozřejmě také hodně štěstí, bez něhož se neobejde žádná lidská činnost, má-li být úspěšná.

Helena Kubátová 